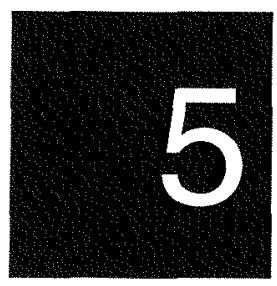

\title{
Improving security of access to customary-owned land in Melanesia: mining in Papua New Guinea
}

\section{Ron Duncan and Rod Duncan}

This chapter takes as its starting point that land ownership arrangements in the South Pacific will continue to change very slowly. Therefore, existing forms of customary or communal ownership will remain in place for a long time. This does not necessarily pose the problem for economic development that many perceive: that communal ownership means insecurity of access for potential users of the land, reducing the incentive to invest in the land with adverse consequences for productivity. As, for example, Crocombe (1995) says, the form of ownership of land is not as important for making the most productive use of the land as the security of access to use of the land. Communal ownership of land should not entail inefficient use of the land as long as security of access to use of the land can be guaranteed.

Accepting that the form of ownership is not as important as security of access, the key question is: how can access for use, essentially through leasehold tenure, be made more secure? In particular, we focus on the situation in Papua New Guinea where access for use seems very insecure, with frequent claims for additional compensation arising after the contract between the lessee and the landowners has been signed. The most prominent examples of this behaviour are in mining projects. However, similar situations have arisen in many other forms of land use, such as hotel construction, timber contracts, and the siting of 
telecommunication facilities. This insecurity of access which results from the post-contract signing claims for additional compensation is very detrimental to investment. As well as reducing the level of investment below what it would be with more secure access, the investment that does take place tends to be of shorter duration. A policy of 'get in and get out quickly' is encouraged. In mining and forestry, for example, this behaviour leads to the best ore grades and the best trees being taken first and with as little attention as possible paid to the resulting environmental effects. ${ }^{1}$

It is a key proposition of this chapter that the solution to the problem of insecurity of access to use of land is to create a contract that is more appropriate to the situation in these countries than contracts presently in use, or to adopt other mechanisms that will lead to fewer disputes or to quicker resolution of disputes over contracts and therefore provide greater security to lessees and greater satisfaction to landowners and the government. The main characteristics of mining in Papua New Guinea which lead to disputes appear to be the following: first, at the time of the contract negotiations there is a high degree of asymmetry in the information available to the mining company on the one hand and to the landowners on the other hand with respect to three very uncertain variables-the size and quality of the ore (or oil or gas) reserves, the expected prices for the mining output, and the environmental damage that may be incurred during the life of the mine. Information about the first and last of these three issues becomes better known during the life of the project, especially to the landowners. Because primary commodity prices basically behave as 'random walk' processes, it is not possible to forecast them. However, a mining company will have a much better understanding of the (usually highly volatile) behaviour of primary commodity prices than will the landowners. Over the life of the project the landowners will see higher and lower prices being paid for the minerals or crude oil but, given the usual form of royalty payments, may not feel that they are sharing fairly in the fortunes of the projectparticularly in the windfall gains from high prices.

Second, the history of land leases in Papua New Guinea shows that landowners are prone to take quite dramatic action in support of their complaints and renewed claims for compensation. The forced closure in 1989 of the Panguna mine on Bougainville island in the North Solomons Province of Papua New Guinea and the court case in 19951996 over the Ok Tedi mine are the two most prominent examples. 
The Mt Kare gold mine site in the Enga Province was subjected to disruption and closure over the period 1991-1992, leading to the mining company CRA Ltd relinquishing its exploration lease in 1993. At a micro level, the electricity and telecommunications bodies, for example, have reported damage being done to their transmitter stations during disputes over landowner claims for additional compensation.

Third, as stated previously, because of the insecurity of tenure, the mining companies (or timber contractors) will, where scope exists, bias their activities towards short-run exploitation of the resource. In addition to the high-grading of ore bodies mentioned, manifestations of this kind of attitude include flying expatriate labour in and out of the mine site rather than constructing permanent living quarters, constructing roads and bridges without long-lasting foundations, minimising on waste disposal facilities, and no longer providing longterm skills training of indigenous labour.

Fourth, in the context of mining in Papua New Guinea, the national government cannot be treated as a neutral agent, simply providing the institutional environment within which contracts are negotiated. At times the government acts as a facilitator of the negotiations between the landowners and the mining companies. It may also form a partnership with landowners in contract negotiations. But the government also acts in competition with landowners over shares in the mining rents (see Gupta 1992 on the history of the BCL mine in Panguna, Bougainville) and has itself made claims for additional compensation (royalties, taxes) and additional equity (as, for example, with the Porgera mine) during the course of agreements. Hence, in the analysis it may be useful at times to treat the government and the landowners as one decision-maker and at other times as competitors. But in looking for ways to improve the security of contracts, it is also useful to examine separate government roles in negotiating contracts with mining companies as well as in holding parties to their agreements.

For purposes of analysis we use a framework drawn from the economic literature on contracts, including the literature relating to labour strikes. Economic analysis of strikes provides a framework which incorporates behaviour closely paralleling those described above. The analysis highlights the major deficiencies of existing forms of mining contracts, given those factors which are seen as leading to disputes, and suggests actions that should reduce disputes over contracts and thereby improve security of access. 


\section{The analytical framework}

As described above, a major problem with mining contracts in Papua New Guinea has been the tendency for the PNG landowners to demand re-negotiation of a contract during the life of the contract. Such actions adversely affect investment by increasing the insecurity of tenure. We have identified four major areas in which these difficulties may arise under long-term contracts for resource use in Papua New Guinea. These broad areas can be thought in terms of

- asymmetry of information between the landowners/ government and the company over the expected profitability of the mine

- time inconsistency of long-term contracts

- incompleteness of the contracts

- disagreements between the PNG landowners and government over the allocation of benefits of the mining contracts.

\section{Informational asymmetry}

Starting with Ashenfelter and Johnson (1969) and surveyed in Kennan (1986), a popular model in the analysis of the economics of labour strikes has incorporated the notion that, lacking as much information about firms' profitability as the firms themselves, unions use strikes to sort out the more profitable firms from the less profitable. It is assumed that the strikers make the firms a decreasing sequence of wage offers, knowing that the more profitable firms will want to resolve the strike sooner than the less profitable firms as the former have more to lose in terms of forgone profits.

This model appears to provide a partial explanation of why it is that the landowners might seek to renegotiate a mining lease. In the absence of full disclosure by the mining company, it seems reasonable to assume that the mining company has much better information about the expected profitability of the mine than the landowners and the government, and thus of the size of possible royalties. Of course, the mining company will have even better information about its expected profitability once it has begun operations. Thus it may be in the interest of the landowners to shut down the mine, or threaten to shut it down, and demand renegotiation of the mining contract once it has begun operation in order to determine better the profitability of the operation. 
Such behaviour seems an exceedingly inefficient manner of gaining information on mine profitability. If the company and the landowners / government knew the final result of the negotiations in advance, they could settle the dispute immediately and both be better off than by undergoing a prolonged mine closure. This anomaly is known in the economics of strikes literature as the 'Hicks Paradox', from Hicks (1963). Due to the asymmetry of information between the parties, the settlement cannot be made in advance because the company has an incentive to under-report profits in order to reduce the payment of royalties. The truthful revelation of company profits is only enforced by the actuality or possibility of a closure.

A reinforcing reason for mine disputes may be provided by factors giving rise to what is known as the time inconsistency of contracts.

\section{Time inconsistency of contracts}

After the issue was raised by Barro and Gordon (1983) in relation to inflation policy, economists realised how ubiquitous problems with respect to time inconsistency are in economic relations. Most agreements will specify future actions to be taken by each party to the agreement. The problem may arise, however, that even if the actions specified are optimal for a party at the time of the making of the agreement, when the time comes to perform the action, the action may not be optimal. This problem may occur even when all events have been perfectly forecasted.

If a way cannot be found to ensure that each party adheres to the agreement, the optimal agreement is time-inconsistent. The parties may have to resort to a sub-optimal agreement that is time-consistent. We will illustrate the problem using a simple example.

Assume the PNG government grants a mining lease. The contract sets out the royalties and other payments the mining company must pay in return for the right to mine over the period of the lease. The time-inconsistency problem arises in that the government or landowners have an incentive to attempt to renegotiate the contract once the company has installed the mining equipment. The initial negotiations will be over the profit of the mine net of the operating and capital costs. Once the capital is installed, however, the company will keep mining as long as it covers its operating costs. Hence, the nature of the negotiations changes as the value covered by the negotiations switches to profit net only of operating costs. The pie is larger and so, presumably, will be the government's new share. 
If the company suspects that the government or landowners will attempt to reopen negotiations once the capital is installed, the company will minimise its installed capital. This will lower the profitability and length of life of the mine and possible royalties, and thus the company, the government and the landowners are worse off than if the government could promise not to renegotiate.

Another way in which time inconsistency may appear in mining contracts is in relation to the insurance role of such contracts. PNG landowners/government should be the more risk-averse party in contract negotiations with a large and diversified mining company which can borrow at prime rates on world capital markets. As such there is scope for the mining company to provide insurance for the PNG government/landowners in the event of a lower than expected mineral price or a poorer ore quality. This difference in risk preference could be accommodated in a mining contract by having a larger portion of the benefits of the contract made in payments that do not depend on the profitability of the mine, such as in lease payments for the land or in infrastructure investment.

If mine profitability turns out to be low, the PNG government/ landowners will be pleased that they took a larger part of the payments from the mine in a manner that was not affected by the low profitability. However, if the mine is more profitable than expected, the PNG landowners/government would have preferred not to have taken the insurance in the first place, but rather to have negotiated a higher share in the equity of the mine. In that case we would expect to see demands for renegotiation of the contract and a larger share of the mine equity on the part of the PNG landowners/government. This is exactly what happened in the case of the Porgera mine.

Knowing that the PNG landowners/government will want to forgo the insurance if the mine is highly profitable, the mining company will be less willing to provide insurance in the 'bad' state. As the provision of insurance in such a contract is to the benefit of both parties, this time inconsistency will mean that both parties are worse off than if demands for renegotiation could be prevented.

The problem of time inconsistency on the part of the government could be circumvented by a device that allows a present government to bind future governments not to renegotiate the mining lease. The sovereign nature of governments and the wide-ranging powers that they wield, however, means that binding future governments is exceedingly difficult. A usually effective restraint on governments 
reneging on contracts is the adverse impact that such action would have on investment in the country. As was seen following the PNG government's decision in late 1992 to increase unilaterally its share of equity in the Porgera mine (although allowed under the Mining Act), such behaviour can result in considerable loss in investor confidence and in capital flight (see ANUTECH Pty Ltd 1995 for estimates of capital flight from Papua New Guinea in the early 1990s). Once governments learn this lesson, it is easier for existing governments to bind the actions of future governments.

It is more difficult for current generations of landowners to bind the actions of future generations of landowners. The dispute over the Bougainville mine is a case in point. It was triggered by a younger generation disappointed in the benefits that they perceived themselves receiving from the mine on the one hand, and the environmental damage which they saw being inflicted on their land on the other.

Thus the possibility of inter-generational competition among landowners adds further elements of time inconsistency. Not only may the later generations of landowners place different values on environmental factors than the generation negotiating the contract, but the initial generation may place less value on the happiness of later generations and so attempt to bring forward the payments under the mining lease at the expense of later generations. The later generations may thus desire that the earlier generations had made a different contract, and not act under the contract as the earlier generations would have wished them to act. Both of these problems played a role in the Bougainville dispute.

The appearance of a new set of decision-makers with different desires not taken into account under the contract is an example of what is called an incomplete contract, which is another common difficulty of long-term mining contracts in Papua New Guinea.

\section{Incomplete contracts}

Incompleteness of contracts arises when an event occurs that was not detailed in the contract, either due to the undue cost of making a complete contract or the inability of one or both of the parties to foresee the event. Typically with mining contracts, such incompleteness arises due to the resource price being much higher or lower than the parties expected or the ore body being richer or poorer than expected. However, unforeseen environmental damage or intergenerational conflicts may also give rise to this problem. 
In practice, it would be hard to differentiate disputes arising from this source from the more opportunistic disputes due to the time inconsistency problem. Unless the contract specified bounds for the resource price or ore quantity/quality, a party could claim that some event had occurred for which it was not prepared and ask for a renegotiation.

As detailed in Deaton and Laroque (1992), the distribution of commodity prices over time is highly skewed downwards with a small probability of very high price spikes. They explain the form of the distribution as due to the existence of inventories and the long lead time required to increase production. When demand is very high and new production will take some time to reach the market, the price rises to clear the market at the given stock of inventories. When demand is very low, however, inventory will be accumulated and suppliers will not sell, so the price will have a floor.

The occurrence of upward price spikes, sharply increasing the profit of the mine, has brought about several demands for increased compensation or renegotiation of mining leases in Papua New Guinea. Improved prospects of ore bodies and observation of environmental damage have also led to changes or demands for changes in contract terms. The increase in the government's equity share in the Porgera mine was as a result of the discovery of the ore body being larger than initially believed. The Bougainville dispute was triggered in large part by observation of the large profits being earned by the mining company in a period of high prices, as well as by perceptions of environmental damage from the mine (Gupta 1992). The Ok Tedi dispute arose largely as a result of concerns over environmental damage, particularly outside the mine lease area. The role played by international political groups exerting influence through international media and foreign governments also has to be acknowledged.

While a price spike may merely provide an excuse for renegotiations for the reasons outlined earlier, another rationale is that the price rise has driven the mine profits out of the region anticipated by the PNG landowners/government in the initial negotiations. The PNG landowners/government may then feel that they do not have a fair share of the windfalls from the price rise. The contracts have provided for landowner royalties involving a payments schedule which is linear in the commodity price. It may be the case that outside of the anticipated range of the commodity price, the PNG landowners would prefer a nonlinear payment schedule, gaining more than proportionately for very high prices. 
Contracts have indeed provided for this nonlinearity as far as the government is concerned. PNG mining and petroleum contracts include an Additional Profits Tax which takes effect when the rate of return of a project (for a Special Mining Lease only) exceeds a specified level. The rate of return is calculated on the basis of the cash flow of the project up to and including the year of income. The determination of the cash flow includes development and, within certain limits, exploration expenditure. The government's holding of equity also ensures participation in boom prices. There is not a similar provision for landowners to share in extraordinary increases in revenues as a result of increases in prices of mine products or improvements in mine output except where the landowners hold an equity share. The Mining Act gives the state an option to take up to 30 per cent equity (on a prorata basis) in new projects. Beginning with the Lihir mine, the government decided in 1995 to provide 5 per cent equity to landowners out of the government's equity share. The landowners' equity share will be provided to them free of charge with the cost to be covered by the other equity holders in proportion to their shares. As discussed above, royalty payments and equity are mechanisms for sharing in high profitability situations; however, they do not provide insurance in the event of low profitability situations. Equity shareholding also internalises disputes by creating a link between land ownership interests and company interests and could be one of the most effective means of curbing disputes raised by landowner interests.

Large-scale mining contracts may have environmental impact much worse than that envisaged by the parties at the signing of the contract, or the impact may be of a type that was completely unforeseen. In the case of Ok Tedi it seems fair to say that the mining company did not have a full appreciation of the difficulty of building and maintaining a tailings dam in that mountainous area. Moreover, it may not have been possible for it to have a good appreciation prior to undertaking mine construction. It is certain that the landowners in the Boungainville and Ok Tedi areas would not have had full information about the environmental effects of mining.

Another possibility is that the landowners will change over time, and the new landowners may place different values on environmental factors. Later generations of landowners may be willing to pay for a tailings dam, where earlier generations did not value cleaner water enough to warrant the construction of a dam. If the mining contract has not specified what would happen in such events, conflicts may arise. 


\section{Disagreements between PNG landowners and government}

It is important to realise that each of the above difficulties can occur at either the level of the PNG landowners or at PNG governmental level or at both levels, although they have been much more frequent on the part of the landowners. One feature of the Bougainville conflict was that while the government was satisfied with the agreement, the Bougainville landowners felt that their share of the profits of the mine was too small.

An example of the interaction of these problems is that of the Additional Profits Tax (APT) put forward in the previous section as a solution to the nonlinearity of desired payments. While the higher profits tax may satisfy the PNG government in its demand for an equitable share, unless the government passes on at least part of the payments from this tax to the PNG landowners, the landowners may feel unfairly treated.

Another reason for this problem being particularly severe in Papua New Guinea is that landowners as a whole do not feel that the government represents their interests, or that certain landowner groups feel that they are left out of consideration in the contract negotiations. It is fair to say that the ownership of below-ground resources is highly contested in Papua New Guinea. While the government is able to appropriate most of the mining rents, its right to do so is hotly disputed. Current mining laws grant the state rights of ownership of below-ground resources but at the same time acknowledge rights of landowners by granting them rights to royalties and equity. This ambiguity is probably one of the greatest sources of insecurity in access rights and needs somehow to be removed. Further, there is not necessarily a single, cohesive landowner group. Landowner groups may exist within the project area with different interests in the mining project wishing the government to pursue their different interest. As well, those landowners living outside the mining site and not sharing directly in the equity and royalty proceeds, can be adversely affected through environmental damage. They may also feel aggrieved at the government for not protecting their interests. The Ok Tedi court case was instigated as a result of such dissatisfaction.

\section{Solutions/recommendations}

In this section we address each of the above four difficulties in turn, suggesting means by which the government and the mining 
companies may alleviate the problems giving rise to disputes. It must be recognised that doing so is in the interest of all parties concerned. If foreign companies perceive the PNG investment climate as uncertain, or even capricious, levels of foreign investment will suffer accordingly.

These recommendations are made on the basis of the following three considerations

- PNG land and mining claims are not secure

- none of the parties involved can be bound absolutely by contract

- up to a point it is cheaper to forestall difficulties than it is to face disputes later.

The problem of asymmetric information can only be solved by increasing the information flow and degree of trust between the mining company and the PNG landowners and the government. It should be recognised by companies operating in this environment that problems of mistrust can only be resolved by ensuring that the PNG government and landowners perceive the companies as being honest. This problem could be addressed by

- regular and timely release of information by the company

- placement of PNG representatives within the structure of the mining company

- use of a third-party auditor to assure the truthfulness of the reports by the company.

Implementation of Development Forums (see McGavin 1993) is a process put in place by the government to assist in imparting knowledge about each projected mining venture to the landowners and provincial and national governments and as a forum for negotiating the mining development contract. McGavin discusses ways in which the Development Forum process could be enhanced to generate stronger commitment to economic development processes. Mining companies have placed PNG nationals within the company structure. But probably more could be done to establish a reputation for honest dealings through regular publication of information on mining operations and independent auditing of that information.

The problem of time inconsistency is hardly unique to Papua New Guinea. The ultimate form of time inconsistency is the nationalisation of foreign company capital, a common experience for mining companies in developing countries in the 1970s. One reason why such activities are not more common is the chilling effect that such actions have on other investments, as experienced in Papua New Guinea 
following the 1992 decision to increase government equity in the Porgera mine from 10 per cent to 30 per cent. The demand for renegotiations from one mining company can lead other companies to suspect that similar demands will soon be made on them. The fear of loss of reputation will normally be sufficient to guarantee that governments will honour the contracts they sign. However, the emphasis within the political class in Papua New Guinea on distribution of the resource rents rather than on economic growth-with one result being the rapid turnover of politicians at election time and another the instability of political parties-means that such reputation effects are lessened. Hopefully, the important lesson from the Porgera decision has been learned. Mining companies, as well as the PNG population, should be crucially concerned with the development of a stable political framework within Papua New Guinea.

While the stability of PNG governments can only be enhanced by constitutional and social change, reputation effects can be strengthened by creating bodies which will monitor contracts and make public the likely impacts of governmental misbehaviour. The creation of a body reporting to the parliament rather than to the government on the fiscal activities of the government, similar to the German Economic Commission, has been suggested as a means of ensuring sound fiscal behaviour (ANUTECH Pty Ltd 1995). Such a body should restrain government misbehaviour by being in a position to draw public attention to the difficulties it creates for economic development.

For very long-term mining leases the problem of time inconsistency introduced by disputes between generations of landowners becomes especially pronounced. Again it is in the interests of the company and the PNG government to prevent these disputes from occurring. The front-loading of lease payments by current landowners at the expense of later generations can be avoided by the use of a trust fund for landowner benefits.

The PNG government already has a trust fund for holding mining royalties and other government revenues from mining, the Mineral Resources Stabilisation Fund. These funds are basically held in trust for the society as a whole. Mining companies and Landowner Incorporated Groups have also set up trust funds. Ok Tedi Mining Ltd manages a trust fund for future generations of landowners and for villages outside the Ok Tedi mine lease area. The creation of a trust fund with specified draw-down rules for the lease payments to landowners would prevent the current landowners from benefiting at the expense 
of future landowners. The BCL mine at Panguna (Bougainville) did have a landowners' trust fund in place but its mismanagement was one of the sources of dissatisfaction of the younger generation. Guidelines for ensuring good management and effective draw-down rules for public trust funds are set out in Duncan et al. (1995).

McGavin (1993) advises that lease payments from resource extraction projects be invested in the infrastructure of the same region from which the resources were extracted through Development Trusts. The problems with this course of action are

- restricting investment to particular areas does not necessarily maximise the country's social rate of return

- there is no guarantee that benefits will flow from these projects to later generations

- such investment projects are easily corrupted, producing benefits only for the current generation of landowners and politicians.

The incompleteness of contracts can only be addressed by widening the scope of the original negotiations, specifying the payments that will occur under even quite unlikely levels of ore prices and ore quality and environmental damage. Parties must consider what actions will be taken in such circumstances and cannot claim to have been taken by surprise if such events do occur. It is also important that all parties likely to be affected should be brought into the negotiations.

There is a requirement for a fully public and widely-framed environmental impact statement for any proposed mining project. However, not only should the possibility of widespread environmental effects be taken into account under a proposed mining lease, but also the mining company and the government should ensure that compensation for any damage flows on to those landowners affected. The inability of the government to enforce compensation arrangements, and to change these where necessary, has proven to be a problem. To assist resolution of such disputes at low cost it seems advisable to appoint an independent mediator to rule in environmental disputes. The problems associated with not undertaking this kind of action are illustrated by the adverse impact that the OK Tedi compensation claim had on the mining company involved and the government.

But no contract can specify all possible future events. Accepting this, all contracts should specify a method of arbitration and airing of grievances by all affected parties. This procedure would allow for periodic review of the terms of the contract, given changing economic 
and other conditions, and hopefully lead to grievances being taken up within the specified arbitration sphere and not against the mining company capital. Such arbitration should include the possibility of changing environmental preferences of the landowners. Of course, this review process is less necessary when the contract is more widely drawn initially.

The Panguna mine contract which was renegotiated in 1974 following Independence provided for renegotiation at seven-year intervals. There was an extended process of review in 1981 and 1982 but, as McGavin (1993) argues, political distractions facing the national and provincial governments allowed the later review period to be bypassed.

\section{Conclusions}

This chapter illustrates the problems leading to insecurity of land tenure in mining in Papua New Guinea in terms of asymmetry of information, time-inconsistency of contracts and incompleteness of contracts as well as the areas of conflict between the landowners and the PNG government. These difficulties are not confined to land use in mining. Likely solutions to the insecurity of tenure in mining, which can have such adverse impacts on investment, can be applied to contracts for land use in other activities. Resolution of the difficulties with mining contracts would appear to be assisted by implementation of the following measures.

1. Increasing the information flow between the mining company and the PNG landowners/government and trying to develop a greater degree of trust in the information provided.

2. Widening of the issues covered in the contract and including all parties likely to be affected in the negotiations. The terms of the contract should cover events such as unusually high prices, new discoveries of ore bodies and environmental effects which may be seen to have only a low probability, and agreement reached on what should be done if they do occur. In particular, landowners should share in the windfall gains of high prices just as the PNG government does already. Equity shareholding by landowners in mining ventures is one mechanism for achieving this objective as well as being a means of internalising disputes by aligning land interests and voting interests in the mining company. 
Landowner royalty payments could also be enhanced by a similar mechanism to the Additional Profits Tax.

Intergenerational competition between landowners should be catered for through adoption of trust funds which would pay an income stream to future generations.

3. Contracts should allow for formal arbitration procedures to handle grievances rather than attempting to resolve these through the courts.

4. Contracts should specify periodic reviews of fees and royalties. However, the wider the terms of the contract are drawn, the less will be the need for reviews.

5. The government should take action to improve its reputation with investors. A body to review fiscal behaviour has much to commend it.

These recommendations may also have application to forms of land use other than mining. It should be stressed, however, that a necessary condition for Papua New Guinea, and other Pacific island countries, to be able to provide greater security of access to use of land is better identification of landownership, which will entail surveys and registration of land. But saying this is not the same as saying that forms of land tenure have to be changed. As we said at the beginning, communal ownership of land does not necessarily mean that access to use of the land is insecure.

\section{Notes}

Our thanks to Rohan Pitchford for pointing to the parallels between behaviour over mining contracts in Papua New Guinea and the assumptions underlying the 'strike model' in labour economics and for other comments on the draft. Very useful comments were also made by Satish Chand, Ross Garnaut, Desh Gupta and Ila Temu.

1. Pitchford (1994) finds that Victorian and Tasmanian policies of short forest tenure and small or uncertain size of forest leases in the early years of this century led to inefficiently low levels of capital and high levels of labour, and likely encouraged timber-cutting firms to adopt poor silvicultural practices.

2. In August 1996, vehicles and sheds were burnt near the Porgera mine by villagers claiming compensation in excess of the US $\$ 2.4$ million agreed for the loss of access to alluvial gold deposits. The incident occurred a few days after the announcement that the mine's gold reserves had been re-estimated at a 35 per cent higher level than previously -an increase worth about US $\$ 1$ billion. 
3. The Mining and Petroleum Working Committee, set up in November 1988 in response to the outbreak of the Bougainville dispute, in fact recommended that the landowners share in APT (Gupta 1992).

\section{References}

ANUTECH Pty Ltd, 1995. 'Papua New Guinea: improving the investment climate', International Development Issues 39, AusAID, Canberra.

Ashenfelter, O. and G. Johnson, 1969. 'Bargaining theory, trade unions and industrial strike activity,' American Economic Review 59:35-49.

Barro, R.J. and D.B. Gordon, 1983. 'Rules, discretion and reputation in a model of monetary policy,' Journal of Monetary Economics 12(1):101-21.

Crocombe, R., 1995. 'Overview' in R. Crocombe (ed.) Customary Land Tenure and Sustainable Development: complementarity or conflict? South Pacific Commission, Noumea and The Institute of Pacific Studies, University of the South Pacific, Suva.

Deaton, A.S. and G. Laroque, 1992. 'On the behaviour of commodity prices,' Review of Economic Studies 59:1-23, January.

Duncan, R., P. Larmour and C. Hunt, 1995. "Held in trust": the role of public funds in economic management', Pacific Economic Bulletin 10(2):41-7.

Gupta, D., 1992. The Law and Order Crisis in Papua New Guinea: An Economic Explanation, NRI Seminar Paper 1, The National Research Institute, Port Moresby.

Hicks, J.R., 1963. The Theory of Wages, Macmillan, London.

Kennan, J., 1986. 'The economics of strikes', in O. Ashenfelter and R. Layard (eds), Handbook of Labor Economics, Elsevier Science Publishers, New York:1091-1137.

McGavin, P.A., 1993. 'Economic Security in Melanesia: key issues for managing contract stability and mineral resources development in Papua New Guinea, Solomon Islands, and Vanuatu', Pacific Islands Development Program Research Report Series 16, East-West Centre, Honolulu.

Pitchford, R., 1994. 'Underinvestment and timber rights: an examination of the early Tasmanian and Victorian timber industries', The Australian Journal of Agricultural Economics 38(3):251-69. 